\title{
PENDIDIKAN AGAMA ISLAM DAN BUDI PEKERTI DALAM MEMBANGUN KERUKUNAN BERAGAMA (TINJUAN KURIKULUM 2013 DI SD TEGALSARI, SRIGADING, BANTUL)
}

\begin{tabular}{l} 
INFO ARTIKEL \\
\hline Riwayat Artikel: \\
Diterima: 02-09-2019 \\
Disetujui: 30-10-2019
\end{tabular}

Keywords:

Curriculum;

Islamic Education;

Good Character;

Religious Harmony.

\section{Kata Kunci: \\ Pendidikan Agama Islam; Budi Pekerti; \\ Kerukunan beragama.}

\author{
Samsudin
IQ An Nur Yogyakarta, Indonesia \\ Samsudin
Fakultas Tarbiyah IIQ An Nur Yogyakarta, Indonesia \\ seamsudin.a1@gmail.com
}

\begin{abstract}
ABSTRAK
Abstract: Recognizing the conflict in Indonesia, which is predominantly Muslim, Indonesia is still vulnerable to conflict. Among the emergence of conflict above is the attitude of exclusivism who views their own belief as the most correct. This study aims to determine the urgency of Islamic education and good character of elementary schools in Curriculum 2013 in the contect of inculcating the religious harmony values to the students. This type of research is a field study, with qualitative research. While the object in this study is Elementary School (SD) Tegalsari, Srigading, Sanden, Bantul. Data collection method uses interviews, observation, and documentation, then it is analyzed. The results of this study indicate that in an effort to build religious harmony in Indonesia, Islamic Education (PAI) and good character have a significant role. Curriculum 2013 in PAI learning and good character in inculcating religious harmony values includes helping and cooperating, living in harmony, behaving politely, sympathizing and tolerant, respecting friends according to the content of QS al Kafirun (paragraph 6). Curriculum 2013 which has been taught at SD Tegalsari in PAI learning and good character is still general and has not 'touched' specifically, only limited to habituation in their daily life, but in general Curriculum 2013 has a significant role in fostering religious harmony.
\end{abstract}

\begin{abstract}
Abstrak: Menyadari konflik di Indonesia yang mayoritas penduduknya muslim, Indonesia masih rentan dengan konflik. Di antara munculnya konflik adalah adanya sikap eksklusivisme yang memandang keyakinannya sendiri yang paling benar. Penelitian ini bertujuan mengetahui urgensi pendidikan Islam dan budi pekerti di Sekolah Dasar (SD) dalam Kurikulum 2013 dalam konteks menanamkan nilai-nilai kerukunan beragama pada siswa. Jenis penelitian ini adalah studi lapangan, dengan metode penelitian kualitatif. Sedangkan obyek dalam penelitian ini adalah Sekolah Dasar Tegalsari, Srigading, Sanden, Bantul. Metode pengumpulan data menggunakan wawancara, observasi, dan dokumentasi kemudian dianalisis. Hasil penelitian ini menunjukkan bahwa dalam upaya membangun kerukunan beragama di Indonesia, Pendidikan Islam (PAI) dan budi pekerti memiliki peran yang signifikan. Kurikulum 2013 pada pembelajaran PAI dan budi pekerti yang diajarkan dalam menanamkan nilai-nilai kerukunan beragama di antaranya adalah tolong menolong dan kerja sama, hidup rukun, berperilaku santun, simpati dan toleran, menghargai teman sesuai dengan kandungan Q.S al Kafirun ayat 6 . Kurikulum 2013 yang diajarkan di SD Tegalsari pada pembelajaran PAI dan budi pekerti masih bersifat umum belum menyentuh secara khusus, hanya sebatas pembiasaan dalam kehidupan sehari-hari, tetapi secara garis besar kurikulum tersebut memiliki peran yang signifikan dalam menumbuhkan kerukunan beragama.
\end{abstract}

\section{A. LATAR BELAKANG}

Indonesia merupakan negara yang mayoritas penduduknya beragama Islam dan beraneka ragam budaya, adat, agama, dan berbagai kepercayaan lainnya yang harus dipelihara. Keanekaragaman tersebut tidak begitu saja tercipta tanpa adanya seluruh elemen masyarakat yang didukung oleh sikap saling toleran. Banyak persoalan yang dapat menimbulkan pertikaian salah satunya akibat perbedaan keyakinan agama. ${ }^{1}$

Mengenai konflik keagamaan, Abdul Mustaqim menjelaskan penyebab yang diisyaratkan dalam alQur'an. Pertama, fanatisme berlebihan yang mendorong orang hanya melihat kelompoknya yang paling benar. Kedua, sikap ekstrem dalam beragama yang memicu bertindak keras dan tidak toleran terhadap agama lain dan anti perdamaian. Ketiga, saling merendahkan dan memberikan

${ }^{1}$ Abd. Rachman Assegaf, Studi Islam Kontekstual Elaborasi Paradigma Baru Muslim Kaffah(Yogyakarta: Gama Media, 2005), hlm. 211. 
pelabelan negatif antara kelompok satu dengan yang lainnya. ${ }^{2}$ Agama pada dasarnya tidak menjadi konflik, akan tetapi pemahaman umat terhadap agama telah membawa konflik dan kekerasan. Persoalan tersebut menjadi pangkal kesulitan dalam membangun kerukunan umat beragama.

Perbedaan dan keragaman di Indonesia ini bukanlah hal yang harus dinegasikan, melainkan harus diterima dan dipelihara supaya menjadi salah satu kekayaan bangsa Indonesia sebagai negara Indonesia yang agamis dan demokratis. Pendidikan agama Islam di Indonesia ini selalu dihadapkan dengan tantangan yang serius yang membutuhkan ekstra dari pemerintah, kalangan pendidikan, dan masyarakat.

Dalam UUD 1945 pasal 29 ayat 1 disebutkan: "Negara menjamin kemerdekaan tiap-tiap penduduk untuk memeluk agamanya masingmasing dan untuk beribadah menurut agamanya dan kepercayaannya itu."3 Oleh karena itu, sebagai warga negara, sudah sepatutnya kita menjunjung tinggi sikap saling menghargai antar umat beragama. Dalam al-Qur'an, Allah Swt. berfirman:

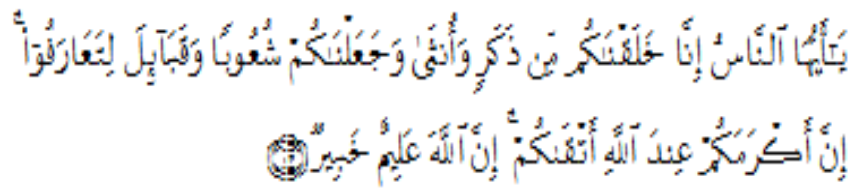

Artinya: Hai manusia, Sesungguhnya Kami menciptakan kamu dari seorang laki-laki dan seorang perempuan dan menjadikan kamu berbangsa-bangsa dan bersuku-suku supaya kamu saling kenal-mengenal. Sesungguhnya orang yang paling mulia diantara kamu disisi Allah ialah orang yang paling taqwa di antara kamu. Sesungguhnya Allah Maha mengetahui lagi Maha Mengenal. (QS. al-Hujuraat [49]: 13).

Menurut Abdurrahman Wahid, sebagaimana dikutip oleh Dr. Phil Shahiron Syamsudin, agama dapat dijadikan sebagai alat pemersatu bangsa, khususnya dalam menerjemahkan Islam rahmatanlil 'alamin, yaitu Islam sebagai pembawa rahmat bagi seluruh alam semesta. ${ }^{4}$ Oleh karena itu, usaha pemerintah dalam menumbuhkembangkan kondisi masyarakat Indonesai yang beragam keyakinan, antara lain dengan menumbuhkan sikap inklusif dan toleran antar pemeluk agama melalui pendidikan agama Islam dan budi pekerti. Dengan demikian, anak akan tertanam akhlak yang mulia sehingga mampu

2 Abdul Mustaqim, Konflik Teologis dan Kekerasan Agama Perspektif Tafsir al-Qur'an(Yogyakarta: Program Pasca Sarjana UIN Sunan Kalijaga, 2011), hlm. 11.

${ }^{3}$ Dahlan Thaib, Kedaulatan Rakyat Negara Hukum dan Konstitusi (Yogyakarta: Liberty Yogyakarta, 1999), hlm. 89.

${ }^{4}$ Kedaulatan Rakyat, Senin 22 Januari 2018, hlm. 9. menjadi pribadi yang dapat hidup berdampingan dengan agama lain.

\section{B. METODE PENELITIAN}

Jenis penelitian ini adalah studi lapangan (field research) dengan metode penelitian kualitatif yaitu memahami dan menafsirkan makna suatu peristiwa i. Sedangkan obyek dalam penelitian ini di SD Tegalsari, Srigading, Sanden Bantul dan yang menjadi informan penelitian ini adalah Kepala Sekolah, dan Guru Pendidikan Agama Islam. Selanjutnya dalam proses pengumpulan data menggunakan tiga tehnik yaitu wawancara, observasi, dan dokumentasi.

Wawancara ini digunakan untuk memperoleh data berkaitan dengan urgensi PAI dan budi pekerti dalam membangun kerukunan beragama. Teknik observasi ini digunakan untuk mengamati lokasi penelitian secara langsung seperti mengamati keadaan lingkungan sekolah. Sedangkan dokumentasi ini digunakan untuk mengetahui kurikulum 2013 dan pengembangan materi yang terdapat dalam buku pendidikan agama Islam dan budi pekerti yang berkaitan dengan cara guru menumbuhkan kerukunan beragama pada anak usia dasar. Sementara untuk pengecekan keabsahan data dalam penelitian ini dengan triangulasi.

\section{HASIL DAN PEMBAHASAN}

\section{Pendidikan Agama Islam dan Toleransi}

Pendidikan agama Islam merupakan rangkaian usaha membimbing dan mengarahkan potensi manusia sehingga terjadi perubahan dalam pribadinya sebagai makhluk individu dan sosial. Proses tersebut senatiasa berada dalam nilai-nilai Islam, yaitu nilainilai yang melahirkan norma-norma syariah dan akhlaqul karimah.

Faktor kemuliaan akhlak dalam pendidikan dinilai sebagai faktor kunci dalam menentukan keberhasilan pendidikan khususnya pendidikan agama Islam. Dalam kehidupan manusia, tingkah laku atau kepribadian merupakan hal yang sangat penting sekali, sebab aspek ini akan menentukan sikap identitas diri seseorang. Baik dan buruknya seseorang itu akan terlihat dari tingkah laku atau kepribadian yang dimilikinya. $^{5}$

Membincangkan pendidikan agama adalah membicarakan keyakinan. Oleh karena itu, Pendidikan agama Islam dan budi pekerti tidak hanya dipahami sebatas pengajaran agama saja, sebab keberhsilannya tidak cukup diukur dari seberapa jauh peserta didik menguasai hal-hal yang bersifat kognitif

${ }^{5}$ Samsudin, "Relevansi Hukuman dengan Pembelajaran HumanisReligius", dalam Jurnal An-Nur: Jurnal Studi Islam, Vol. VI, No. 1, th. 2014, hlm. 65 . 
atau pengetahuan tentang ajaran agama Islam semata, lebih-lebih dari penilaian angka-angka. Penekanan yang lebih penting dalam pendidikan agama Islam dan budi pekerti adalah seberapa dalam tertanamnya nilainilai keagamaan yang tampak nyata dalam perilaku keseharian peserta didik, yaitu akhlak yang mulia.

Oleh karena itu, tujuan dari semua agama Islam adalah membina seluruh manusia agar memiliki kepribadian yang baik dan bermoral. Intisari dari ajaran agama Islam dan budi pekerti sesungguhnya berkisar pada penjelasan tentang hal yang baik dan buruk, sebagai contoh ajaran Islam memberikan tuntutan kepada pemeluknya agar berbuat baik dan saling menghormati sesama manusia.

Manusia juga mempunyai tanggung jawab bersama dalam menciptakan keharmonisan dalam kehidupan sosial. Kontribusi sosial yang ditekankan oleh agama Islam ialah kebaikan bukan berbuat kerusakan di muka bumi, sebagaimana firman Allah Swt. berikut:

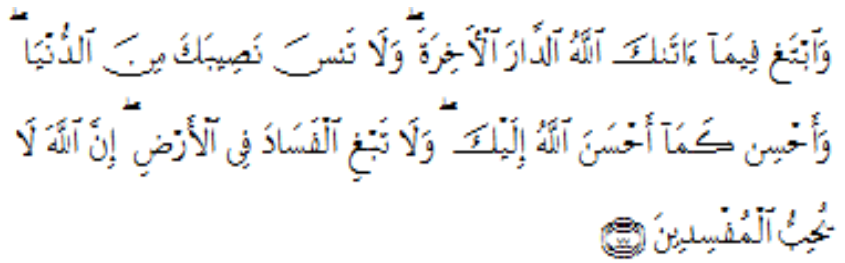

Artinya: dan carilah pada apa yang telah dianugerahkan Allah kepadamu (kebahagiaan) negeri akhirat, dan janganlah kamu melupakan bahagianmu dari (kenikmatan) duniawi dan berbuat baiklah (kepada orang lain) sebagaimana Allah telah berbuat baik, kepadamu, dan janganlah kamu berbuat kerusakan di (muka) bumi. Sesungguhnya Allah tidak menyukai orang-orang yang berbuat kerusakan. (QS. al-Qashash [28]: 77).

Dalam kandungan ayat tersebut, dijelaskan bahwa Allah melarang manusia berbuat kerusakan, saling membenci, dan berselisih di antara sesamanya di muka bumi. Oleh karena itu, pendidikan agama Islam yang di ajarkan di sekolah dasar memiliki peran yang sangat penting dalam upaya membentuk kehidupan yang harmonis di tengah-tengah masyarakat yang plural.

Menurut Sutrisno, pendidikan agama Islam adalah usaha yang sistematis dalam mengembangkan fitrah beragama peserta didik sehingga menjadi manusia yang beriman, bertakwa, dan berakhlak mulia serta aktif membangun peradaban dan keharmonisan kehidupan, khususnya dalam memajukan peradaban bangsa yang bermartabat. ${ }^{6}$ Sementara, menurut Majid dan Dian Andayani, pendidikan agama Islam adalah upaya sadar dan terencana dalam menyiapkan

${ }^{6}$ Sutrisno, Pembaruan dan Pengembangan Pendidikan Islam (Yogyakarta: Fadilatama, 2011), hlm. 160. peserta didik untuk mengenal, memahami, menghayati, hingga mengimani ajaran agama Islam, dibarengi dengan tuntunan untuk menghormati penganut agama lain dalam hubungannya dengan kerukunan antar umat beragama yang hingga terwujud kesatuan dan persatuan bangsa. ${ }^{7}$

Dalam kandungan ayat tersebut, Allah memerintahkan umat Islam untuk bersatu bukan bercerai berai yang hanya menuruti hawa nafsu. Jadilah manusia yang selalu menjunjung tinggi nilai-nilai persaudaraan (ukhuwah) dengan mengikuti apa yang ada pada diri Nabi Muhammad Saw. dan para sahabatnya yang selalu membangun persatuan, bukan perpecahan umat. Dalam Q.S. Al An'am: 153, Allah berfirman:

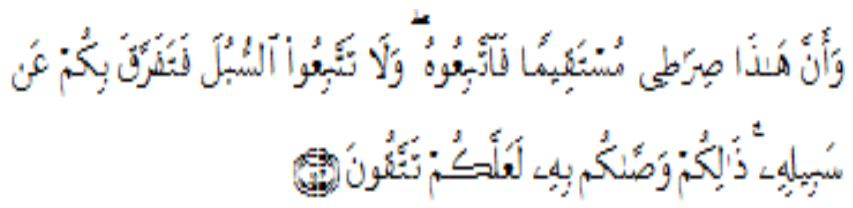

Artinya: dan bahwa (yang Kami perintahkan ini) adalah jalanKu yang lurus, Maka ikutilah Dia, dan janganlah kamu mengikuti jalan-jalan (yang lain), karena jalan-jalan itu mencerai beraikan kamu dari jalanNya. yang demikian itu diperintahkan Allah agar kamu bertakwa. (Q.S. Al An'am: 153.)

Dalam hadist Nabi Muhammad SAW. di jelaskan:

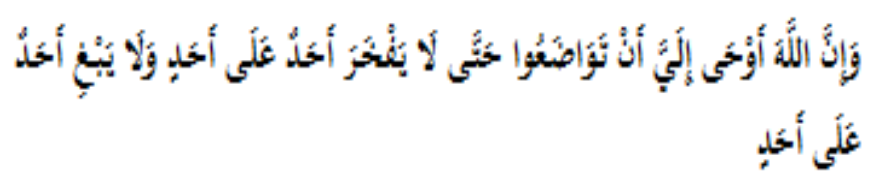

Artinya: dan Alah mewahyukan kepadaku agar kalian saling merendah diri agar tidak ada seorang pun yanga berbangga diri pada yang lain dan agar tidak seorang pun berlaku dzalim pada ornag lain. (H.R Bukhari Muslim)

Di dalam kandungan Al-Qur'an dan hadis di atas mengandung anjuran untuk selalu bertakwa dan sikap saling merendah diri (tawadhu). Sebab, kedua hal tersebut adalah akhlak yang mulia dalam Islam yang dapat dijadikan senjata sebagai pemersatu umat. Seseorang yang punya iman yang kuat dan akhlak mulia terhadap sesama akan melahirkan hubungan persaudaraan umat yang kuat dan tercipta kerukunan hidup beragama.

Dengan demikian, umat Islam akan bangkit menjadi umat yang dapat mewujudkan Islam rahmatan lilalamin yang mampu mengintegrasikan pengamalan ibadah ritual dan esensi ibadah itu

${ }^{7}$ Abdul Majid dan Dian Andayani, Pendidikan Agama Islam Berbasis Kompetensi; Konsep dan Implementasi Kurikulum 2004 (Bandung: Remaja Rosdakarya, 2004), hlm. 130. 
sendiri yang termanifestasi dalam kehidupan sehari-hari, seperti saling menghormati, bersikap toleran, bukan saling menghujat. Dengan sikap yang demikian umat Islam dapat membangun negara baldatun thayibatun warabbun ghafur, yaitu negara yang subur dan makmur dengan penuh pengampunan dari Allah SWT.

\section{PAI dan Budi Pekerti dalam Menumbuhkan Kerukunan Beragama}

Dalam upaya menumbuhkan kerukunan beragama, pengembangan kurikulum pendidikan agama Islam dan budi pekerti di sekolah sangatlah perlu. Dengan pengembangan kurikulum dan materi yang diajarkan pada anak akan bermanfaat bagi dirinya sendiri dan orang lain serta negara yang harmonis. Keharmonisan inilah menjadi salah satu yang harus dicapai melalui pendidikan agama Islam dan budi pekerti untuk mewujudkan persatuan dan kesatuan serta kerukunan dalam beragama khususnya di masyarakat Indonesia yang beragam.

Dengan demikian, kerukunan beragama merupakan kondisi ketika setiap penganut agama dapat bersikap terbuka dan menerima segala perbedaan serta memberikan rasa aman dan rasa nyaman dalam menjalankan aktivitas dalam kehidupan sehari-hari. Masyarakat yang selalu menjaga dan memberikan rasa aman tanpa mengganggu satu dengan yang lainnya akan tercipta kerukunan dalam beragama.

Pendidikan agama Islam dan budi pekerti memiliki peran penting dalam membangun kerukunan beragama. Sebab, agama Islam adalah agama yang mengajarkan segala kebaikan yang dibutuhkan seluruh umat manusia. Persoalan pendidikan agama Islam, adalah persoalan yang menyangkut kehidupan manusia yang senatiasa berkembang dalam kehidupan sosial. Oleh karena itu, keberadaan pendidikan agama Islam dapat menjadi obat dalam menyelesaikan perpecahan umat Islam di Indonesia. ${ }^{8}$

Dalam pendidikan agama Islam dan budi pekerti terdapat materi yang memuat akhlak terpuji yaitu berperilaku baik terhadap sesama agar mereka dapat hidup berdampingan dengan baik. Itulah salah satu ajaran Islam yang terdapat dalam pendidikan agama Islam dan budi pekerti. ${ }^{9}$ Menurut Ai Siti Nurhamidah, tujuan pendidikan agama Islam, juga tidak pernah lepas dari membicarakan tujuan hidup manusia sebagai makhluk sosial yang dilandasi iman yang kuat.

\footnotetext{
2019.

${ }^{8}$ Hasil wawancara dengan kepala Sekolah SD Tegalsari 1 oktober

${ }^{9}$ Suparno Ahmad, Pendidikan Agama Islam dan Budi Pekerti, (Yogyakarta: Yudistira, 2019), hlm. 118
}

Untuk itu, dalam merumuskan tujuan pendidikan agama Islam dan budi pekerti harus fleksibel yang terus menerus disesuaikan dengan perkembangan zaman sesuai dengan ajaran Islam. ${ }^{10}$

Muhammad Thalib menuturkan bahwasanya tujuan pendidikan agama Islam adalah menjadikan manusia yang mau mempergunakan semua sarana yang telah Allah sediakan untuk kehidupan dunia sebagai jalan untuk beramal saleh dengan niat mencari keridaan Allah. Dengan rumusan tujuan ini, ilmu yang didapat semata-mata digunakan untuk menggali segala kebajikan yang dapat dilakukan oleh manusia agar dapat menjalankan amal shalih sebanyak-banyaknya dan dapat memberi manfaat kepada sesama manusia tanpa memandang status sehingga hal-hal yang merugikan manusia dapat dicegah. ${ }^{11}$

Dalam ruang lingkup pendidikan agama Islam dan budi pekerti juga dijelaskan bahwa pendidikan agama Islam tidak hanya membahas tentang hubungan manusia dengan Tuhannya melainkan juga terdapat hubungan manusia dengan manusia lain yang harus dipenuhi sebagai wujud ketakwaan kepada Allah. Hubungan manusia dengan manusia ini adalah saling menghargai, menghormati dan saling membantu, serta saling memberikan rasa nyaman.

Menurut Ai Siti Nurhamidah kerukunan beragama merupakan keadaan bebas konflik. Artinya, walaupun kita berbeda agama kita tetap bersatu dengan sikap saling menghormati, saling membantu dan kerja sama, bukan saling membenci. Jika dalam kehidupan sehari-hari anak dapat saling membantu dan saling menghargai masyarakat Indonesia akan bebas konflik. Di sinilah pentingnya menumbuhkan nilai-nilai kerukunan beragama pada anak usia dasar salah satunya melalui materi dalam pendidikan agama Islam dan budi pekerti dalam kurikulum 2013. ${ }^{12}$ Dengan demikian, jelaslah bahwa pendidikan agama Islam memiliki peran yang sangat besar dalam menciptakan kerukunan beragama. Apabila agama Islam tidak bisa menciptakan kerukunan umat beragama maka agama Islam akan kehilangan jati dirinya sebagai agama yang rahmatan lilalamin, yaitu agama yang membawa kedamaian umat manusia.

Kerukunan dalam beragama merupakan sesuatu yang menjadi dambaan setiap orang. Manusia sebagai makhluk sosial harus hidup berdampingan dengan menjunjung nilai-nilai perdamaian. Oleh karena itu, hubungan sesama

\footnotetext{
${ }^{10}$ Hasil waawncara dengan guru PAI SD Tegalsari 1 Oktober 2019

${ }^{11}$ Muhammad Thalib, 20 Kerangka Pokok Pendidikan Islam, (Yogyakarta: Ma'alimul Usroh, 2001), hlm. 18.

${ }^{12}$ Wawancara dengan guru PAI tanggal 1 Oktober 2019
} 
manusia walaupun berbeda agama juga harus tetap dijaga dan dipelihara serta dilestarikan melalui proses pendidikan agama Islam agar tercipta kerukunan umat beragama. Kerukunan dan perdamaian inilah sebagai wujud agama Islam yang rahmatanlilalamin yakni agama membawa kedamaian dan bebas konflik.

Dalam kurikulum 2013 pendidikan agama Islam dan budi pekerti di SD Tergalsari, materi yang berkaitan dengan nilai-nilai kerukunan beragama di antaranya adalah

1. Tolong Menolong dan Kerja Sama

Perilaku terrpuji dalam Islam dikenal dengan akhlak mulia. Sedangkan materi akhlak terpuji dalam kurikulum 2013 kelas 2 ini, menyakut materi tolong menolong dan kerja sama dalam kehidupan sehari-hari. ${ }^{13}$ Tolong menolong dan kerja sama ini merupakan sikap kekeluargaan yang harus ditanamkan pada diri anak melalui pendidikan dasar. Oleh karena itu, dalam upaya menciptakan kerukunan beragama tolong menolong dan kerja sama merupakan modal penting dalam menjalin kerukunan beragama.

2. Hidup Rukun

Rukun adalah sifat yang penuh dengan persahabatan. Rukun merupakan sikap untuk bersedia hidup berdampingan dengan orang lain yang memiliki perbedaan dengan kita. Adapun ciriciri anak yang rukun di antaranya adalah tidak membeda-bedakan teman, senang membantu dan menghargai pendapat orang lain, dan tidak suka mengganggu orang lain, suka menolong dan bekerja sama dalam kebaikan. ${ }^{14}$ Hidup rukun ini dapat dilakukan di rumah, sekolah dan di masyarakat. Dalam upaya membangun kerukunan beragama, hidup rukun sangat perlu ditanamkan pada anak usia dasar agar anak memiliki kebiasan hidup berdampingan tenpa membeda-bedakan status.

\section{Berbaik Sangka}

Berbaik sangka bagian dari akhlak terpuji yaitu menduga yang baik terhadap sesuatu. Banyak hikmah yang terdapat dalam sikap berbaik sangka di antaranya adalah hidup tenang dan selalu berfikir yang jernih, selalu optimis, berusaha dan bertawakal, dan selalu berharap dan bertawakal pada Allah serta tidak mudah putus asa. Perilaku akhlak terpuji yang dimiliki oleh setiap umat beragama sangat penting dalam kehidupan seharihari baik berkata maupun bertingkah laku. Oleh karena itu, pembiasaan sejak usia dasar menjadi pondasi dalam membangun kerukunan beragama.

\section{Perilaku Santun dan Menghargai Teman}

Santun merupakan sikap seseorang yang saling menghargai dan bersikap lemah lembut dan tingkah laku yang halus. Santun tidak hanya ditunjukan kepada orang yang lebih tua saja melainkan dengan sesama teman. Orang yang mempunyai sifat santun adalah orang yang tahu tentang akhlak dan orang yang memiliki akhlak terpuji akan disegani banyak orang. ${ }^{15}$

Dengan demikian, penanaman sikap santun pada anak usia dasar menjadi hal yang sangat penting, sebab anak yang memiliki sikap halus, tutur katanya lembut, menghargai teman, dan tidak pernah menyakiti hati orang lain serta santun kepada siapa saja, ini menjadi pondasi dasar pada anak untuk hidup berdampinan tanpa memandang status atau keyakinan orang lain.

5. Sikap hormat dan Menghargai Pendapat

Sikap saling menghrmati merupakan sikap yang sangat peting untuk diajarkan pada setiap anak, karena dengan sikap saling menghormati antar sesama tidak akan terjadi kekerasan, perkelahian dan konflik. Sedangkan sikap menghargai pendapat adalah sikap menghormati apa yang menjadi pikiran atau usaha orang lain. ${ }^{16}$ Dengan demikian, dalam kehidupan sehari-hari perlu menerapkan sikap saling menghormati dan menghargai dengan siapa saja tanpa memandang agama atau golongan, baik di lingkungan sekolah maupun lingkungan tempat tinggal.

6. Perilaku Toleran dan Simpati terhadap Sesama

Toleransi adalah sikap tegang rasa atau menghargai pedirian orang lain yang berbeda dengan pendirian sendiri. Dalam buku pedoman pendidikan agama Islam dan budi pekerti dijelaskan bahwa dalam toleransi dibagi menjadi 3 macam yaitu, toleransi antar sesama muslim, antar umat beragama dan antar suku bangsa. ${ }^{17}$ Sedangkan simpati adalah rasa kasih, rasa suka atau keikutsertaan merasakan perasan orang lain. ${ }^{18}$

Dalam kehidupan berbangsa dan bernegara, terdapat kehidupan berbagai macam pemeluk agama atau penganut kepercayaan berbeda-beda. Sikap toleransi dan simpati ini perlu ditanamkan pada anak sejak usia dasar melalui proses pendidikan agama Islam dan budi pekerti, agar umat beragama di Indonesia terjalin dengan baik dan bebas konflik.

7. Kandungan Q.S al Kafirun: 6

${ }^{13}$ Suparno Acmad, Pendidikan Islam dan Budi Pekerti: Kelas 2,

\footnotetext{
${ }^{15}$ Ibid., kelas IV. hlm. 35.

${ }^{16}$ Ibid., kelas V. hlm. 40.

${ }^{17}$ Ibid., kelas VI. hlm. 122-123.

${ }^{18}$ Ibid., kelas IV. hlm. 124.
} 
Dalam Q.S al-Kafirun khususnya ayat 6, yakni "untukmu agamamu dan untukulah agamaku"19 ini menjadi dasar keimanan seorang Islam, agar berpegang teguh pada agama yang diyakininya yaitu Islam. Akan tetepi, dari sisi muamalah anak harus menghormati dan menghargai sesama tanpa memandang status.

Berkaitan dengan kerukunan beragama, ini perlu dijelaskan pada anak usia dasar bahwa sebagai seorang Islam harus yakin pada agama yang diyakininya (akidah). Sedangkan dari sisi muamalah harus bertoleran pada agama lain untuk tetap hidup saling tolong-menolong, Iman seseorang tidak akan sempurna jika kita tidak saling menghargai. Oleh karena itu, agar iman kita mencapai kesempurnaan maka dalam kehidupan sehari-hari harus saling membantu orang lain tanpa memandang agama yang dianutnya.

Itulah beberapa materi dalam kurikulum 2013 yang diajarkan dalam pembelajaran pendidikan agama Islam dan budi pekerti dalam menumbuhkan kerukunan beragama pada anak. Sub materi yang diajarkan di SD Tegalsari hanya memuat nilai-nilai kerukunan hanya sebatas pembiasaan dalam kehidupan sehari-hari, akan tetapi kurikulum tersebut memiliki peran yang signifikan dalam membangun toleransi beragama. Kerukunan merupakan modal utama dalam membangun keharmonisan bangsa yang plural. Oleh karena itu, Tanpa terwujudnya adanya sikap saling menghormati, toleran, dan santun antar agama, bangsa Indoensia akan mudah terpecah.

\section{SIMPULAN DAN SARAN}

Kerukunan beragama merupakan dambaan bangsa Indonesai. Untuk menumbuhkan kerukunan beragama, Pendidikan agama Islam dan budi pekerti memiliki peran yang sangat signifikan. Dalam upaya menumbuhkan nilai-nilai kerukunan beragama pada siswa di SD Tegalsari, terdapat dalam kurikulum 2013 dalam pembelajaran pendidikan agama Islam dan budi pekerti di antarnya adalah tolong menolong dan kerja sama, hidup rukun, berperilaku santun, simpati, toleran, dan menghargai teman serta materi yang kandungan dalam Q.S al Kafirun: 6.

Kurikulum 2013 yang diajarkan di SD Tegalsari pada pembelajaran PAI dan budi pekerti masih bersifat umum, belum menyentuh secara khusus materi kerukunan beragama. Materi yang berkaitan dengan nilai-nilai kerukunan beragama hanya sebatas pada pembiasaan dalam kehidupan sehari-hari, akan tetapi kurikulum 2013 tersebut memiliki peran yang signifikan dalam menumbuhkan kerukunan beragama.

\section{DAFTAR RUJUKAN}

Achmad Suparno. (2019). Pendidikan Islam dan Budi pekerti. Yoyakarta: Yudistira.

Assegaf Rachman. Abd., (2005). Studi Islam Kontekstual Elaborasi Paradigma Baru Muslim Kaffah. Yogyakarta: Gama Media.

Kurniawan Syarif Ahmad. (2013) Membengun Seangat Keharmonisan Kerukunan Umat Beragama di Indonesia: Jurnal Akademika, Vol. XVIII, No. 02.

Lubis Ridwan. (2005). Cetak Biru Peran Agama, Jakarta: Puslitbang.

Mustaqim Abdul. (2011). Konflik Teologis dan Kekerasan Agama Perspektif Tafsir al-Qur'an, Program Pasca sarjana UIN Sunan Kaljaga Yogyakarta.

Majid Abdul dan Andayani Dian. (2004). Pendidikan Agama Islam Berbasis Kompetensi; Konsep dan Implementasi Kurikulum 2004. Bandung: PT. Remaja Rosdakarya.

Rohmad Ali. (2009). Kapita Selekta Pendidikan. Yogyakarta: Teras.

Samsudin. (2014). Relevansi Hukuman dengan Pembelajaran Huamnis Religius: Jurnal An Nur Jurnal Studi Islam, Vol. VI No. 1. hlm. 6182

Sutrisno. (2011). Pembaruan dan Pengembangan Pendidikan Islam, Yogyakarta: Fadilatama.

Thaib Dahlan. (1999). Kedaulatan Rakyat Negara Hukum Dan Konstitusi, Yogyakarta: Liberty Yogyakarta.

Thalib Muhammad. (2001). 20 Kerangka Pokok Pendidikan Islam. Yogyakarta: Ma'alimul Usroh. 